\title{
School environment and school injuries
}

\author{
Simo Salminen ${ }^{1}$, Marja Kurenniemi ${ }^{2}$, Mirka Råback ${ }^{3}$, Jaana Markkula ${ }^{3}$ and Anne Lounamaa ${ }^{3}$ \\ 1 Finnish Institute of Occupational Health, Helsinki, Finland \\ ${ }^{2}$ National Research and Development Centre for Welfare and Health (STAKES), Helsinki, Finland \\ ${ }^{3}$ National Institute for Health and Welfare, Helsinki, Finland
}

Edited by:

Sanjay P. Zodpey, Public Health

Foundation of India, India

Reviewed by:

William Augustine Toscano, University of Minnesota School of Public Health,

USA

Himanshu Negandhi, Public Health

Foundation of India, India

Lalit Raghunath Sankhe, Grant

Government Medical College and Sir

J J Group of Hospitals, India

\section{*Correspondence:}

Simo Salminen, Finnish Institute of Occupational Health, Topeliuksenkatu 41 aA, Helsinki Fl-00250, Finland e-mail:simo.salminen@ttl.fi
Background: Although injuries at school are an important issue in public health, environmental factors in schools and school yards have seldom been the focus of school injury research. The goal of our investigation was to examine the effect of environmental factors on school injuries.

Methods: Nine comprehensive Finnish schools registered school injuries over a period of two school years. Injuries were classified as being associated with environmental factors, suspected environmental factors, and others. The consensus between two independent classifiers was $81 \%$.

Results: A total of 722 injuries were classified. In $11.6 \%$ of these injuries, the physical environment factor was evident, and in $28.1 \%$ of the injuries, physical environment was suspected of being a contributory risk factor. Thus the physical environment of the school was a contributing factor in over a third $(39.7 \%)$ of injuries occurring in the school, on the school yard or during the journey to, or from school. In this study, conducted in Finland, ice on the ground was mentioned most frequently as an environmental risk factor.

Conclusion: In Finland, the Nordic weather conditions are not taken into account in the school yard and playground plans as they ought to from the safety point of view. An initiative has been launched on a mandatory wintertime master plan for every school yard.

Keywords: school injury, school yard, ice, snow, winter

\section{INTRODUCTION}

From the perspective of sociology, schools are one of the basic institutions in the society or perhaps as sub-systems of a society as Parsons (1) wrote. The fact is that schools are working in every society in the world. Thus the safety in schools is essential for the whole society.

In Finland, there are a total of 3026 primary schools, of which $3.1 \%$ were private schools and others are public schools. The average number of pupils was 175 (2). Finnish children between 10 and 14 years of age spent an average of $2 \mathrm{~h}$ and $22 \mathrm{~min}$ in schools every work day (3), whereas in Germany as much as $25-50 \%$ of their waking hours (4). Safety at schools is thus an important factor for public health.

Injuries at school are more common among boys than girls (5-9). However, girls are nearly twice as likely to be injured as boys at the school playground in Tucson, AZ, USA (10). In French schools, girls were injured during sports and physical training more often than boys (11), whereas in Swedish schools boys injured more often during sports and breaks (12).

Playgrounds exceeded all other sites of school injury for all age groups concluded a review of literature (6). However, another review showed that playground injuries were more frequent in elementary schools or kindergartens than in secondary schools (13). For instance, injury-risk situations occurred every 3 min among schoolchildren playing in a New England school playground. Boys were involved in these situations more often than girls, and were more likely to perform aggressive actions. Climbing and swinging equipments, in particular the slide, were identified as contributors to injury-risk situations (14). The injury rate at playgrounds was more than twice that of sports areas among, for example, Vancouver elementary school students (15). Fractures also occurred most often at playgrounds among elementary school children in Seattle (16), as did almost one fourth (23\%) of school injuries in Alexandria, Egypt (17).

In Greek schools, playgrounds were dry during the occurrence of $74 \%$ of injuries, and the playground was covered by asphalt in $29 \%$ of cases (18). Head injuries were more frequent at the playground, whereas injuries to the lower and upper extremities were most frequent during sports in Swedish schools (19). There was a difference of up to 40 times in rates of equipment injury between schools in Tucson, AZ, USA (20). Playground equipment caused $38 \%$ of all playground injuries in Boulder Valley School District in Colorado (21) and the injury rate in Utah school playgrounds covered by asphalt was six times higher than that of those covered by sand (22). Hard surface on playground increased only boys' activity (23). Playground injuries differed in their nature and body site affected from injuries sustained on the athletic field or in the gym (21).

Breaks and physical education lessons are school time which is spent on school grounds including playgrounds. A review showed 
that access to equipment, permanent play structure, and marked courts facilitated the physical activity of pupils during breaks (24). A total of $85 \%$ of injuries in Swedish schools occurred during breaks and physical education (25) which together comprised about one third of school time (26). The rate of injuries was also slightly higher in unorganized play or free time than during organized athletic programs in Hawaiian schools (27). In Poland, $37 \%$ of school injuries for pupils aged $7-15$ years occurred during breaks, and 33\% during physical education (28), while in Germany, $47 \%$ of school injuries were related to sports, $30 \%$ to playtime, and $17 \%$ to classroom lessons for all school-aged (29). Ball games and especially soccer has the greatest risk of school injury (2931). Urban environment increased the risk of school injury both in Poland (28) and in China (32). Larger schools with equipment with full-size gymnasium had a higher school injury rate in Poland (28). On the contrary, in Japan the injury rate of pupils was highest in the small-sized schools (33).

Wintertime in Finland (December to February) is the most critical time period for school injuries. A previous study in the Turku region in Finland shows that most school injuries occurred in October and November and from January through March (34). This study revealed that the first ice storm before the real winter was also a critical time for injuries due to falls.

As the literature review showed together with activity, environmental factors are important potential causes of school injuries. However, the contribution of environmental factors to school injuries has not been studied yet except studies with playground equipments (20) and school environment checks in Sweden (35). The aim of this study was to examine the role of environmental factors in school injuries in Finland. This is done from the viewpoint of architecture, which means that the physical and built environment is the focal point. The built environment included playgrounds, its equipment, the floor, and playground cover, but not machines, balls, and moving equipment. It means also that school environment is looked at the point of planning.

\section{MATERIALS AND METHODS}

As a part of a larger project on school injuries in Finland (36), nine comprehensive schools from four Finnish cities registered injuries. The total number of pupils was 2900 and their age ranged from 7 to 15. The schools participated in this study on a voluntary basis and registered injuries over a period of two school years: 2002-2003 and 2003-2004. All injuries in which an injury pupil required the treatment of school nurse were included.

An "injury at school" was defined as either an intentional or unintentional injury that caused physical harm to the pupil. A teacher or school nurse filled in a school injury form (one A4 page) immediately after the injury, based on the injured pupil's report. The form was completed for both injuries and violent acts, and the average time required to fill the form was $2 \mathrm{~min}$. The form was same for all of the schools. It is partly based on the Swedish model (13).

The school injury form included a space for short description of the injury. During initial meetings with school staff and school nurses, researchers discussed how to write descriptions. The classification of the injuries as environmental factor, a suspected environmental factor, or a non-environmental factor as a cause is based on these written descriptions. The classification was carried out by two researchers independently (Marja Kurenniemi, Simo Salminen). The classification reliability was estimated by the consensus of the results of these two independent classifications. Their consensus based on the sample of 100 observations was $81.2 \%$, which is above the acceptable level of $70 \%$ (37). Secondly, the reliability of classification was measured by Cohen's coefficient of kappa (38). Its value was 0.50 (95\% CI: 0.44-0.55) which was moderate agreement. In the case of inconsistency between classifiers the result of the main classifier (Marja Kurenniemi) was used.

An injury was classified as having been caused by an environmental factor where the effect of the environment was obvious and could be estimated to be the main reason for the injury occurrence: for example, pupil stepped on a door holder and fell. A suspected environmental factor concerned injuries in which the environmental factor was seen as a contributing factor but not an immediate cause: for example, the narrowness of a corridor contributing to the collision of pupils, causing injury. If the school environment has been different kind, the school children should behave in safe way in the situations where the injuries happened. Other injuries were classified as: no definite evidence that the environmental played a major role.

\section{RESULTS}

Over half of the injuries recorded in the registry occurred during breaks, and one out of four injuries during sports lessons. Boys were injured more often during breaks, whereas girls sustained injuries more often during sport lessons (36). Almost half $(49 \%)$ of school injuries occurred outdoors. A total of 722 injury forms were classified. In $11.6 \%$ of classified injuries, a physical environment factor was evident, and was estimated to be the most significant factor contributing to the occurrence of the injury. In $28.1 \%$ of the injuries, the environment was considered an important and contributory risk factor. Thus the school environment was a contributing factor in $39.7 \%$ (287) of school injuries.

Table 1 shows the distribution of environmental factors in school injuries. One third of injuries were caused by slippery surfaces. School yard arrangements contributed to one fifth of injuries. Every 12th injury occurred in traffic environment. Other environmental factors had minimal influence on injuries. The following injuries are examples of a clear environmental factor: "A pupil fell down the stairs outside" (injury number 197), and "A pupil slipped and fell on his/her right hand" (injury number 431).

An example of a contributing factor is: "A pupil rode his/her bicycle to the end of the asphalt and fell" (injury number 720). Another injury where the environment was a contributing factor is: "A pupil's left shoulder rubbed against the railing in the swimming pool causing a bruise" (injury number 643). Ice was the most frequently mentioned environmental factor (in 5.8\% of injuries) associated with school injuries in the school yard. For example: "A pupil fell on the icy school ground, breaking one front tooth and splitting a lip" (injury number 42). An example for icy school playground is shown in Figure 1. 
Table 1 | Environmental factors related to school injuries

\begin{tabular}{|c|c|c|c|}
\hline Factor & Frequency & $\%$ & Typical injury \\
\hline Door & 7 & 2.5 & Pinched fingers in the door \\
\hline Chair & 9 & 3.3 & Coming down with a chair \\
\hline Window & 6 & 2.2 & $\begin{array}{l}\text { Sway and window get } \\
\text { broken }\end{array}$ \\
\hline Floor & 4 & 1.4 & $\begin{array}{l}\text { Tumbled down on the } \\
\text { roughness floor }\end{array}$ \\
\hline Steps, handrails & 6 & 2.2 & $\begin{array}{l}\text { Falling on steps with bad } \\
\text { condition }\end{array}$ \\
\hline Playgrounds & 8 & 2.9 & $\begin{array}{l}\text { Get a piece of glass from } \\
\text { playground }\end{array}$ \\
\hline Equipments, slides & 7 & 2.5 & $\begin{array}{l}\text { Jump over bicycle stand } \\
\text { and injured his knee }\end{array}$ \\
\hline Traffic arrangements & 24 & 8.7 & Crash with bicycle to a car \\
\hline $\begin{array}{l}\text { School yard } \\
\text { arrangements }\end{array}$ & 59 & 21.3 & Fall by sand on the asphalt \\
\hline $\begin{array}{l}\text { Space } \\
\text { arrangements }\end{array}$ & 12 & 4.3 & $\begin{array}{l}\text { Fall on the bench of the } \\
\text { corridor }\end{array}$ \\
\hline Slipping & 12 & 4.3 & $\begin{array}{l}\text { Slipping and falling during } \\
\text { the play }\end{array}$ \\
\hline Slippery & 90 & 32.5 & $\begin{array}{l}\text { Slipping on icy school } \\
\text { ground }\end{array}$ \\
\hline Others & 33 & 11.9 & $\begin{array}{l}\text { Football hit to student's } \\
\text { forehead }\end{array}$ \\
\hline Total & 277 & 100.0 & \\
\hline
\end{tabular}

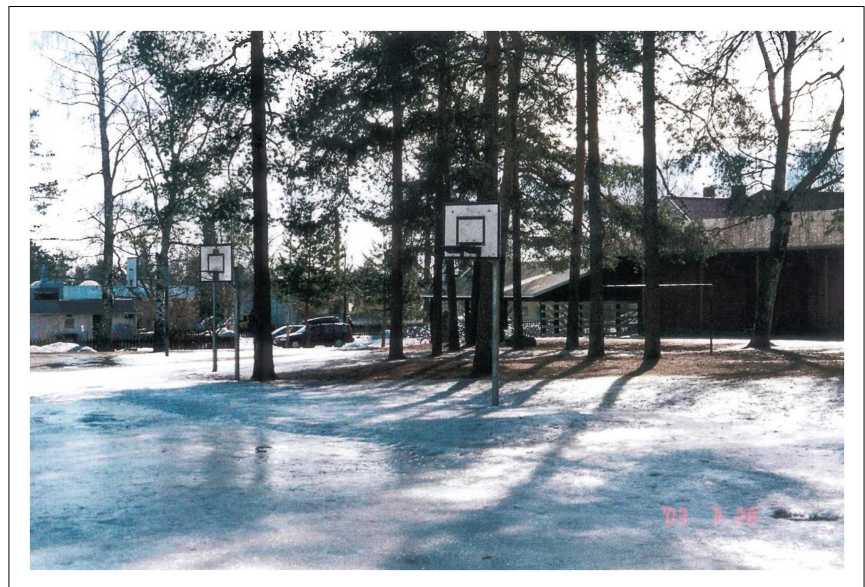

FIGURE 1 |The Finnish school yard during the wintertime.

\section{DISCUSSION}

One of the main conclusions of this study is that in Finland, the architecture of school yards and playgrounds are designed for the summertime, and are not suitable during wintertime, when there is snow and ice on the ground. This explains why there are so many falls in Finnish schools.

Finnish children have long summer vacations, from June to mid-August, and attend school during the winter months. The snow and icy season varies depending on the location of the school: in southern Finland, the season is on average from November to March, whereas in the north it lasts from October to April.

Maintaining school yards during the winter months, recognizing ice as a significant risk factor, following the weather forecast for icy days, and passing on this information to maintenance personnel, could reduce school injuries in countries such as Finland. The results of this study led to a mandatory wintertime master plans for school yards in Finland including first elimination of ice and snow from the school yard and then sanding the yard. The high compensation of school injuries [even \$50,000 Ref. (39)] increased the meaning of the injury prevention.

Another method to prevent injuries at school yards is the safety round method (40). The head master and a group of teachers and pupils walk around the school area and especially school yard observed the risk places of injuries. The important point is the participation of pupils, because they see risks from different perspectives than adults. This safety check should be done annually (41). Importance of this perspective is emphasized by the Lithuanian study with schoolchildren showing that feeling unsafe at school increased the risk of injury (42). Pupils' perception of low justice increased the risk of being dissatisfied with school and absence due to truancy (43).

Rigorous, effective injury prevention efforts at school should address several factors: the environment, individual behavior, social norms, legislation, and policy. Improvements to the physical environment of the school through regular safety assessments, good quality maintenance, and repairing hazards immediately after they are identified, can contribute to school safety. To tackle these challenges, attention should be paid to both organizational and everyday routine practices in schools. In this way, we can guarantee children's rights to a safe environment - a safe school environment.

Environmental modification and increased supervision can reduce school injuries (44). However, increased teacher supervision not necessarily help to prevent injuries, as $88 \%$ of injuries at Missouri schools, for instance, occurred while pupils were allegedly supervised by adults. Supervisor of school children is especially difficult during lunch break (45). High supervision increased both boys' and girls' physical activity at school yards in San Diego (46). On the other hand, a playground injury prevention plan (47) based on the S.A.F.E. model (48) could modify the school yard safer. Schools need also after-school program to prevent injuries in their playgrounds after the school hours (49).

The most important limitation of this study is that the schools participated in this study on a voluntary base. We cannot be sure that they reported all the injuries in their school. For example, Scottish schools under-reported injuries, even those requiring hospital treatment (50). In Canada, schools routinely reported only one out of five injuries and one out of two serious injuries (51). In Wales, a third of primary schools did not report their injuries to the authorities (52). We assume that the schools in this study also under-reported their injuries, but we cannot estimate the extent of this suspected under-reporting. 
The other limitation of this study is that all participating schools situated in the cities. However, majority of 4300 Finnish primary schools worked at the country side, but they have at minimum one teacher and 5-10 pupils. Thus the unknown number of school injuries is a problem only in big schools and in the cities.

\section{REFERENCES}

1. Parsons T. Societies: Evolutionary and Comparative Perspectives. Englewood Cliffs, NJ: Prentice-Hall (1966).

2. Kumpulainen T, editor. Koulutuksen tilastollinen vuosikirja 2011 [Statistical Yearbook of Education, 2011]. Helsinki: Opetushallitus (2012). Available from: www.oph.fi/julkaisut/2012/koulutuksen_tilastollinen_vuosikirja_2011

3. Statistics Finland. Ajankäyttötutkimus 1999-2000 [A time use survey in Finland 1999-2000]. Helsinki: Tilastokeskuksen PX-Web-tietokannat (2008).

4. Kraus R, Heiss C, Alt V, Schnettler R. Schulunfälle - eine Analyse von Verletzungsmustern und Behandlungsaufwand [School accidents - an epidemiological assessment of injury types and treatment effort]. Zentralbl Chir (2006) 131:411-6. doi:10.1055/s-2006-949534

5. Di Scala C, Gallagher SS, Schneps SE. Causes and outcomes of pediatric injuries occurring at school. J Sch Health (1997) 67:384-9. doi:10.1111/j.1746-1561. 1997.tb07182.x

6. Haq SM, Haq MM. Injuries at school: a review. Tex Med (1999) 95:62-5.

7. Li L-P, Wang S, Huang G, Luo J-Y. A survey on injury incidence in school children in Shantou City, China. Biomed Environ Sci (2003) 16:180-6.

8. Sun YH, Yu IT, Wong TW, Zhang Y, Fan YP, Guo SQ. Unintentional injuries at school in China - patterns and risk factors. Accid Anal Prev (2006) 38:208-14. doi:10.1016/j.aap.2005.09.010

9. Sun YH, Yu IT, Zhang Y, Fan YP, Guo SQ, Wong TW. Unintentional injuries among primary and middle school students in Maanshan City, eastern China. Acta Paediatr (2006) 95:268-75. doi:10.1080/08035250500312171

10. Boyce WT, Sprunger LW, Sobolewski S, Schaefer C. Epidemiology of injuries in a large, urban school district. Pediatrics (1984) 74:342-329.

11. Chau N, Prédine R, Aptel E, d'Houtaud A, Choquet M. School injury and gender differentials: a prospective cohort study. Eur J Epidemiol (2007) 22:327-34. doi:10.1007/s10654-007-9118-1

12. Jacobsson B, Bek-Jensen H, Jansson B. One year's incidence of school accidents and their severity in a Swedish municipality. Scand J Prim Health Care (1986) 4:213-7. doi:10.3109/02813438609014834

13. Laflamme L, Menckel E, Aldenberg E. School-injury determinants and characteristics: developing an investigation instrument from a literature review. Accid Anal Prev (1998) 30:481-95. doi:10.1016/S0001-4575(97)00101-2

14. Coppens NM, Gentry LK. Video analysis of playground injury-risk situations. Res Nurs Health (1991) 14:129-36.

15. Sheps SB, Evans GD. Epidemiology of school injuries: a 2-year experience in a municipal health department. Pediatrics (1987) 79:69-75.

16. Johnson CJ, Carter AP, Harlin VK, Zoller G. Injuries resulting in fractures in the Seattle public schools during the school year 1969-70. J Sch Health (1972) 42:454-7. doi:10.1111/j.1746-1561.1972.tb01816.x

17. Kamel MI, Youssef RM, Teleb NA, Atta HY. Epidemiology of school injuries in Alexandria. J Egypt Public Health Assoc (1998) 73:667-90.

18. Christoforidis C, Kambas A. Childhood injuries in Greek school environment. Int J Inj Contr Saf Promot (2007) 14:262-3. doi:10.1080/17457300701619195

19. Laflamme L, Menckel E. School injuries in an occupational health perspective: what do we learn from community based epidemiological studies? Inj Prev (1997) 3:50-6. doi:10.1136/ip.3.1.50

20. Boyce WT, Sobolewski S, Sprunger LW, Schaefer C. Playground equipment injuries in a large, urban school district. Am J Public Health (1984) 74:984-6. doi:10.2105/AJPH.74.9.984

21. Lenaway DD, Ambler AG, Beaudoin DE. The epidemiology of school-related injuries: new perspectives. Am J Prev Med (1992) 8:193-8.

22. Sosin DM, Keller P, Sacks JJ, Kresnow M, van Dyck PC. Surface-specific fall injury rates on Utah school playgrounds. Am J Public Health (1993) 83:733-5. doi:10.2105/AJPH.83.5.733

23. Cardon G, van Cauwenberghe E, Labarque V, Haerens L, de Bourdeaudhuij I. The contribution of preschool playground factors in explaining children's physical activity during recess. Int J Behav Nutr Phys Act (2008) 5:11. doi:10.1186/1479-5868-5-11
24. Davison KK, Lawson CT. Do attributes in the physical environment influence children's physical activity? A review of literature. Int J Behav Nutr Phys Act (2006) 3:19. doi:10.1186/1479-5868-3-19

25. Schelp L, Ekman R, Fahl I. School accidents during a three school-years period in a Swedish municipality. Public Health (1991) 105:113-20. doi:10.1016/S00333506(05)80284-7

26. Hammarström A, Janlert U. Epidemiology of school injuries in the northern part of Sweden. Scand J Soc Med (1994) 22:120-6.

27. Taketa S. Student accidents in Hawaii's public schools. J Sch Health (1984) 54:208-9. doi:10.1111/j.1746-1561.1984.tb08820.x

28. Sosnowska S, Kostka T. Epidemiology of school accidents during a six schoolyear period in one region in Poland. Eur J Epidemiol (2003) 18:977-82. doi:10.1023/A:1025802203726

29. Scherer K, Mausner-Dorsch H, Kemény P. Surveillance-based injury epidemiology in schools in Germany. Int J Inj Contr Saf Promot (2006) 13:159-69. doi:10.1080/17457300600725317

30. Sumilo D, Stewart-Brown S. The causes and consequences of injury in students at UK institutes of higher education. Public Health (2006) 120:125-31. doi:10.1016/j.puhe.2005.01.018

31. Knobloch K, Rossner D, Jagodzinski M, Zeichen J, Gössling T, Martin-Schmitt S, et al. Prävention von Schulsportverletzungen - Analyse von Ballsportarten bei 2234 Verletzungen. Sportverletz Sportschaden (2005) 19:82-8. doi:10.1055/ s-2005-858142

32. Jia C, Zhao Z, Bo Q, Zhang Y, Liu Z. Incidence rates and risk factors for injury events in high school students in Lijin County, China. J Safety Res (2005) 36:133-7. doi:10.1016/j.jsr.2004.12.006

33. Ishigure K. Daily number of accidental injuries among elementary school children and school size factors in elementary schools. Nihon Eiseigaku Zasshi (2007) 62:47-57. doi:10.1265/jih.62.47

34. Sillanpää M, Terho P, Westerén H, Pisirici H. Accidents in schoolchildren: epidemiologic, aetiologic and prognostic considerations. Acta Paediatr Hung (1983) 24:119-30.

35. Laflamme L, Eilert-Petersson E. School-injury patterns: a tool for safety planning at the school and community levels. Accid Anal Prev (1998) 30:277-83. doi:10.1016/S0001-4575(97)00085-7

36. Salminen S, Lounamaa A, Kurenniemi M. Gender and injury in Finnish comprehensive schools. Accid Anal Prev (2008) 40:1267-72. doi:10.1016/j.aap.2008. 01.014

37. Litwin MS. How to Measure Survey Reliability and Validity. Thousand Oaks, CA: Sage (1995).

38. Revelle W. Procedures for Personality and Psychological Research. Evanston: Northwestern University (1990). Available from: http://personality-project.org/ r/psych.manual.pdf, 1.0-90 edition

39. Barrios LC, Jones SE, Gallagher SS. Legal liability: the consequences of school injury. J Sch Health (2007) 77:273-9. doi:10.1111/j.1746-1561.2007. 00203.x

40. Bjärås L, Danielsson K, Schelp L, Sjöberg D, Skjönberg G. Safety rounds in public environments: experience of a new tool for prevention of accidental injuries. Accid Anal Prev (1990) 22:223-8. doi:10.1016/0001-4575(90)90014-C

41. Acosta O, Bosworth K, Brainerd E, Campana J, Dilillo D, Dunne-Maxim K, et al. School health guidelines to prevent unintentional injuries and violence. $M M W R$ (2001) 50(RR-22):1-73.

42. Starkuviené S, Zaborskis A. Links between accidents and lifestyle factors among Lithuanian schoolchildren. Medicina (Kaunas) (2005) 41(1): 73-80.

43. Elovainio M, Pietikäinen M, Luopa P, Kivimäki M, Ferrie JE, Jokela J, et al. Organizational justice at school and its associations with pupils' psychosocial school environment, health, and wellbeing. Soc Sci Med (2011) 73:1675-82. doi:10.1016/j.socscimed.2011.09.025

44. Josse JM, MacKay M, Osmond MH, MacPherson AK. School injury among Ottawa-area children: a population-based study. J Sch Health (2009) 79:45-50. doi:10.1111/j.1746-1561.2008.00375.x

45. Dale M, Smith ME, Weil JW, Parrish HM. Are schools safe? Analysis of 409 student accidents in elementary schools. Clin Pediatr (1969) 8:294-6. doi:10.1177/000992286900800516

46. Sallis JF, Conway TL, Prochaska JL, McKenzie TL, Marshall SJ, Brown M. The association of school environments with youth physical activity. Am J Public Health (2001) 91:618-20. doi:10.2105/AJPH.91.4.618 
47. Olsen HM, Hudson SD, Thompson D. Developing a playground injury prevention plan. J Sch Nurs (2008) 24(3):131-7. doi:10.1622/1059-8405(2008) 024

48. Hudson S, Thompson D. Overview of playground safety. In: Hudson S, editor. The S.A.F.E. Playground Handbook. Cedar Falls, IA: National Program for Playground Safety (2004). p. 1-8.

49. Rosenkranz RR, Welk GJ, Dzewaltowski DA. Environmental correlates of objectively measured physical activity and sedentary behavior in after-school recreation sessions. J Phys Act Health (2011) 8(Suppl 2):S214-21.

50. Stark C, Wright J, Shiroyama C, Lee J. School injuries in the west of Scotland: estimate of incidence and health service costs. Health Bull (1997) 55:44-8.

51. Woodward CA, Milner R, Harsanyi Z, Feldman W, Hodgson C. Completeness of routine reporting of school-related injuries to children. Can J Public Health (1984) 75:454-7.

52. Williams WR, Latif AH, Cater L. Accidents in the school environment: perspectives of staff concerned with data collection and reporting procedures. Public Health (2003) 117:180-6. doi:10.1016/S0033-3506(02)00025-2
Conflict of Interest Statement: The authors declare that the research was conducted in the absence of any commercial or financial relationships that could be construed as a potential conflict of interest.

Received: 19 September 2013; paper pending published: 18 October 2013; accepted: 21 December 2013; published online: 13 January 2014.

Citation: Salminen S, Kurenniemi M, Råback M, Markkula J and Lounamaa A (2014) School environment and school injuries. Front. Public Health 1:76. doi: 10.3389/fpubh.2013.00076

This article was submitted to Public Health Education and Promotion, a section of the journal Frontiers in Public Health.

Copyright (C) 2014 Salminen, Kurenniemi, Råback, Markkula and Lounamaa. This is an open-access article distributed under the terms of the Creative Commons Attribution License (CC BY). The use, distribution or reproduction in other forums is permitted, provided the original author(s) or licensor are credited and that the original publication in this journal is cited, in accordance with accepted academic practice. No use, distribution or reproduction is permitted which does not comply with these terms. 